\title{
Factors Controlling the Development of Wine-Glass Forms in the Mountains of the Kurdistan Region, Iraq
}

\author{
Varoujan K. Sissakian ${ }^{1,2}$, Arsalan A. Othman ${ }^{3}$ and Ahmed T. Shihab ${ }^{4}$ \\ ${ }^{1}$ Department of Natural Resources Engineering and Management, School of Science and Engineering, University of Kurdistan Hewler, \\ Erbil, Kurdistan Region - F.R. Iraq \\ ${ }^{2}$ Private Consultant Geologist Ainkawa, Erbil 44001, Kurdistan Region - F.R. Iraq \\ ${ }^{3}$ Iraq Geological Survey, Sulaymaniyah Office, Sulaymaniyah, Kurdistan Region - F.R. Iraq \\ ${ }^{4}$ Iraq Geological Survey, Al-Andalus Square, Baghdad 10068, F.R. Iraq
}

\begin{abstract}
The northern and northeastern parts of Iraq are mountainous areas and rugged topography with different erosional and morphological forms; among them are the wine-glass (erosional cirques) forms. They are developed in different shapes, sizes, and depths. In the outlets of the wine-glass forms; usually, alluvial fans are formed. The studied area is characterized by the presence of long and narrow anticlines with NW-SE trend that changes westward to $\mathrm{E}-\mathrm{W}$ trend. The Cretaceous carbonate rocks form the main carapace of the majority of the mountains; however, locally Paleogene and/or Jurassic rocks form the carapace. In the core, rocks down to Devonian are exposed. In those anticlines where only Cretaceous rocks are exposed, no or very rarely wine-glass forms are developed. This is attributed to the Cretaceous carbonate rocks, which exist in huge thicknesses in many formations, with thickly bedded to massive nature and very hard erosion resisting rocks. Tens of the existing wineglass forms are studied to indicate the factors that control their development, which are the type of exposed rocks, their thicknesses, and hardness. To perform the aim of this study, different satellite imagery with different resolutions was used; besides using GIS technique and field check to improve the acquired date.
\end{abstract}

Index Terms - Wine-glass form, Erosional-cirque, Alluvial-fan, Cretaceous rocks, Kurdistan Region.

\section{INTRODUCTION}

The northern and northeastern parts of the Iraqi Kurdistan region are located in the Extremely Rugged Mountainous and High Amplitude Mountainous Provinces and form physiographically mountainous areas with very rugged

ARO-The Scientific Journal of Koya University

Volume VI, No 2(2018), Article ID: ARO.10415, 10 pages DOI: $10.14500 /$ aro. 10415

Received 30 April 2018; Accepted 05 December 2018

Regular research paper: Published 20 December 2018

Corresponding author's e-mail: f.khajeek@ukh.edu.krd

Copyright (C) 2018 Varoujan K. Sissakian, Arsalan A. Othman and Ahmed T. Shihab. This is an open access article distributed under the Creative Commons Attribution License. topography (Othman and Gloaguen, 2014, 2013a and b; Sissakian and Fouad, 2012). The relief differences are highly variable in different parts of the studied area, attaining up to $2500 \mathrm{~m}$, and exceptionally more. This rugged topography is attributed to the presence of long and narrow anticlines with the effect of the climatic factors that have contributed to increasing the intensity of the erosion, the water being the main agent. Consequently, the anticlines are deeply dissected by tens of erosional forms, among them are the erosional cirques; they will be called in this study as "wine-glass forms" because many publications dealing with geomorphology in the same area have used the same term.

A cirque is an amphitheater-like valley head, formed at the head of a valley glacier by erosion (Mitchel and Humphries, 2014). However, Gornitz (2009) defined the cirque as "although a less common usage, the term cirque is also used for amphitheater-shaped, fluvial-erosion features." Alternative names for this landform are "corrie" (from Scottish Gaelic coire meaning a pot or cauldron) and "cwm" (Welsh for "valley"). A cirque may also be a similarly shaped landform arising from fluvial erosion (Upton and Wadsworth, 1969); also mentioned by Evans and Cox (1974), Huggett (2007), Gornitz (2009), and Bahrami (2012).

Alden (2014) also defined the cirque or wine-glass form as "A bowl-shaped rock valley on the side of a mountain, often with a glacier or permanent snowfield in it." Moreover, Al-Jaf and Kadhim (2010), Al-Ma'amar et al. (2011), Yacoub et al. (2012), and Sissakian et al. (2014) also have adopted and used the term of wine-glass form in the Iraqi mountainous areas during describing geomorphological features of the northern and northeastern parts of Iraqi Kurdistan region.

Makhtesh is another form of wine-glass, found in karst landscapes it is formed by intermittent river flow cutting through layers of limestone and chalk leaving sheer cliffs (Wikipedia, 2014). This term, however, is not concerned in this study.

The main aims of this study are to discuss the origin and development of wine-glass forms within certain parts of the studied area; their absence in many others and to elucidate the role of the lithology, tectonics, and erosion in their development.

The location of this study extends in the northern and northeastern parts of Iraq, especially, north of latitude $36^{\circ} \mathrm{N}$; 
at the western part and north of latitude $35^{\circ} \mathrm{N}$; at the eastern part (Fig. 1, north of the oblique red line). The coverage area of the studied area is about $59325 \mathrm{~km}^{2}$. The studied area is located, tectonically, in the Outer Platform of the Arabian Plate (Fouad, 2012a). Rocks of different ages are exposed in the studied area; ranging from Triassic to Tertiary (Sissakian and Fouad, 2012); however, the majority of the exposed rocks in which wine-glass forms are exposed belong to the Cretaceous period.

\section{Materials USED AND Methodology}

Many materials were used to achieve the aim of this study, represented by geological maps, at a scale of 1: 100,000 and 1: 250,000, topographical maps, at scale of 1: 100,000, digital elevation model (DEM) and satellite images; such as Landsat and QuickBird data, and relevant published articles and reports. These materials were used to recognize the anticlines, which exhibit wine-glass forms, in the studied area.

Geological maps and reports of the studied area are compiled by Sissakian (1995, 1993), Fouad (2007), Al-Mousawi et al. (2008), Sissakian and Fouad (2014a, $2014 b, 2014 c)$. Moreover, some geological hazard maps and related publications were used too; to indicate extensive erosional areas where wine-glass forms may be developed in the studied area (Sissakian and Al-Jibouri, 2014a; Sissakian and Ibrahim, 2005, 2004a, 2004b; Sissakian, 2013, 2010; Sissakian et al., 2008a, 2008b, 2008c).

Fieldwork was carried out for the period 2006-2012, Sissakian and Fouad (2012) during updating the existing geological maps at different scales in the Iraqi Kurdistan region. The fieldwork was utilized to acquire interesting data, such as type of the exposed rocks in and around the wineglass forms. Some structural data such as the asymmetry of the limbs, size of the folds, and the distance between the folds were also reviewed to elucidate the relationship between the wine-glass forms and the present structural features.

For performing the current work, 20 QuickBird scenes were used. They were obtained through the Ministry of Planning (Iraq) and were acquired from August 18, 2002, to August 29, 2006. These scenes are 8-bit, orthorectified, and radiometrically corrected, with $0.6 \mathrm{~m}$ spatial resolution. Only the three-visible spectral (i.e., blue [450-520 nm], green [520-600 nm], and red [630-690 nm]) bands were processed. These three visible spectral bands data were pan-sharpened using the UNB algorithm (DigitalGlobe, 2006). ArcGIS 10 was used to digitize the wine-glass boundaries, calculate the wine-glass area and prepare base map. The wine-glass form's boundaries were identified from the satellite data based on morphological characteristics such as tone, texture, and the scarps.

\section{Previous Studies}

Although many publications and reports are available for the studied area, none of the existing works have mentioned about the details of the wine-glass forms. Some of these works have dealt with different geomorphological aspects in the studies area such as Hamza (1997). Although he compiled the geomorphological map of Iraq at a scale of $1: 1,000,000$ but he did not represent and/or mention the wine glass forms in the compiled map and/ or the enclosed report. Al-Jaf and Kadhim (2010), Al-Ma'amar et al. (2011) investigated parts of the studied area, too. They compiled the geomorphological map with a scale of 1: 250,000 for Kirkuk Quadrangle, and Erbil and Mahabad Quadrangles, respectively, and mentioned about the presence of the wineglass forms. Yacoub et al. (2012) and Sissakian et al. (2014) compiled the geomorphological map of the low folded zone and the high folded zone in Iraq, respectively, and reported about the presence of many wine-glass forms.

\section{WINE-GLASS FORMS}

\section{A. General}

Wine-glass forms are forms of erosional cirques; they may be formed due to fluvial erosion. Their shape is described as "concave amphitheater shape is open on the downhill side corresponding to the flatter area of the stage, whereas the cupped seating section is generally steep, cliff-like slopes down, which slope debris combine and converge from the three or more higher sides" (Ward et al., 2000).

\section{B. Enlargements of Wine-glasses Forms}

The floor of each wine-glass form ends up bowl-shaped; as it is the complex convergence zone of combining water flows from multiple directions and their accompanying rock burdens, hence, experiences somewhat greater erosion
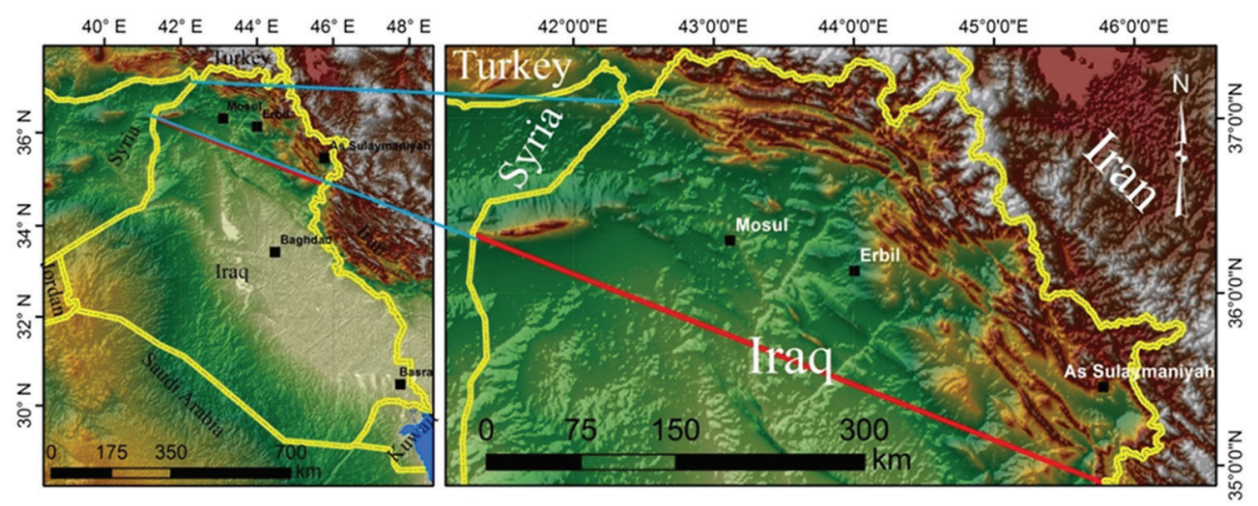

Fig. 1. Digital elevation model GMTED2010 (resolution 30 Arc) overlapping hillshade showing the location of the studied area. 
forces. It is most often over-widened backward (backstage) and sideward of the wine-glass form to conjugate with a neighboring one forming a large wine glass form, and very rarely, many wine-glass forms conjugate each other to occupy the whole core of an anticline; forming one large wine-glass form, usually, with many outlets; representing their original outlet forms.

A good example of enlarged wine-glasses is Gara anticline (Fig. 2). Such large wine-glass forms are formed in the studied area only when soft rocks are exposed in the core of the anticline. The Triassic rocks, represented by Baluti Formation (Late Triassic), which consists of soft shale (Sissakian and Saeed, 2012) are highly weathered and eroded; therefore, all formed wine-glass forms are conjugated together to form one very large wine-glass form that almost occupies the whole core of the Gara anticline (Fig. 2). However, when the core and limbs of an anticline consist of hard rocks and in between them are soft rocks, which are easily eroded forming slopes and/or undulated landscape; then the core is remained, and a large wine-glass form is formed around the core with many outlets (Fig. 3).

The development of large wine-glass forms is attributed to: (1) The presence of hard rocks in the cores of anticlines, (2) the hardcore is dissected by steep valleys that drain the

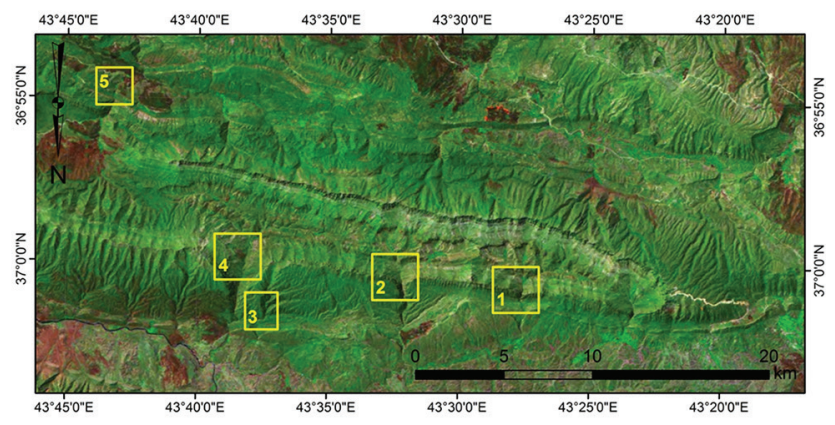

Fig. 2. Landsat image of Gara anticline, facing south. Note, the whole anticline exhibits one extremely large wine-glass form, with three outlets (Nos. 1, 2, and 3, whereas No. 4 is not fully developed) toward the north, and one outlet (No. 5) toward the south. rainwater toward the soft rocks, (3) the soft rocks (Shiranish, Tanjero, Kolosh, and Gercus formations) are easily weathered and eroded forming gentle slopes and longitudinal valleys, (4) the hard rocks of the Qamchuqa, Bekhme, and Pila Spi formations in the outer parts of the anticlinal limbs also play the same role in accelerating the erosion of the soft rocks, (5) the accumulated water finds the easiest discharge area from the outer part of the limb to discharge the water with the sediments out of the anticline because it will represent the weakest and lowest part topographically, and (6) continuously repeated actions have formed many wine-glass forms, which are enlarged with time to conjugate each other and form a very big wine-glass form with special geomorphological form (Fig. 3).

The hard rocks in the core of Bani Bawi anticline belong to the Bekhme Formation (Fig. 3), it consists of very hard dolomite, dolomitic limestone, and limestone, the fairly hard rocks belong to the Shiranish Formation (thinly well bedded marly limestone and papery blue marl), whereas the soft and highly weathered rocks belong to the Tanjero, Kolosh, and Gercus formations (soft clastics). The outer part of the limb is represented by the Pila Spi Formation (well bedded very hard dolomitic limestone) (Sissakian and Fouad, 2012; Sissakian and Saeed, 2012).

\section{Alluvial Fans Related to Wine-Glasses}

A common feature for fluvial-erosion cirques (wine-glass forms) is a terrain, which includes erosion resistant upper structures overlying materials, which are more easily eroded, and often associated with alluvial fans in the outlet of the wine-glass form. The size of the fans depends on the size of the wine-glass forms and the type and the thickness of the exposed rocks that are eroded during forming of the wineglass form. Tens of wine-glass forms are associated with alluvial fans in the studied area; a good example is Pera Magroon anticline with very large developed alluvial fan; called Zewe alluvial fan (Fig. 4; Sissakian et al., 2014). However, some wine-glass forms, although they are large have not developed alluvial fans in their outlets. This is attributed to: (1) The draining valley of the wine-glass form

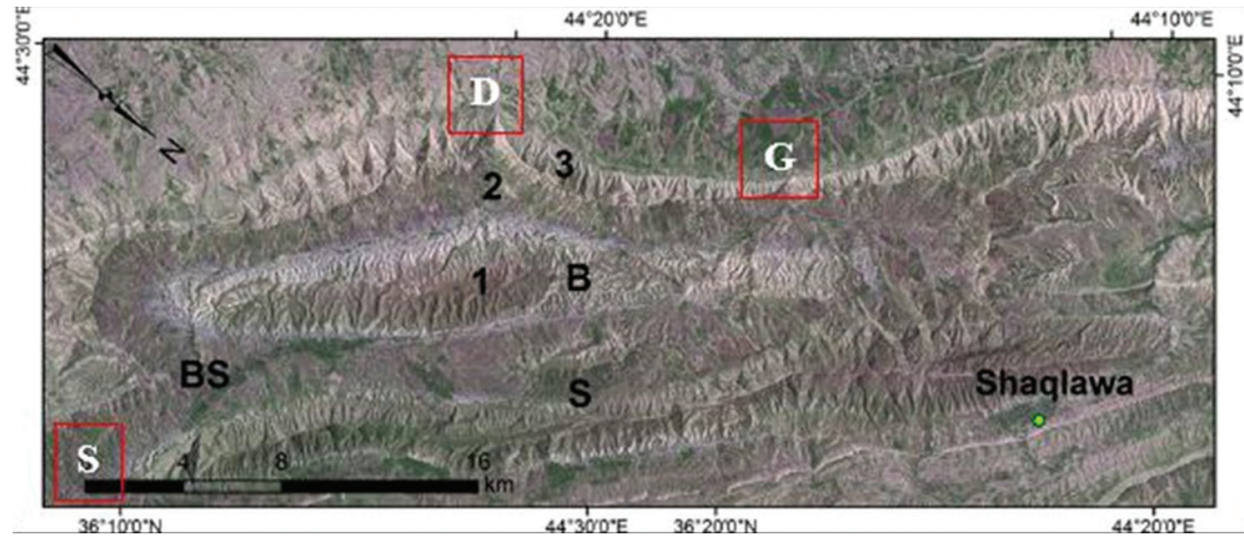

Fig. 3. Landsat image facing N $135^{\circ}$ E showing: (B) Bana Bawi anticline exhibiting extremely large wine-glass form, with three outlets, S) Safeen anticline. Formations: (1) Bekhme, (2) Shiranish, Tanjero, Kolosh, and Gercus, and (3) Pila Spi. (BS) In this location, there is no available space for the development of alluvial fan because it is located between two anticlines. The three outlets are: $\mathrm{G}=$ Gome Ispan, $\mathrm{D}=\mathrm{Degala}$, and $\mathrm{S}=\mathrm{Sma}$ Qualley. 


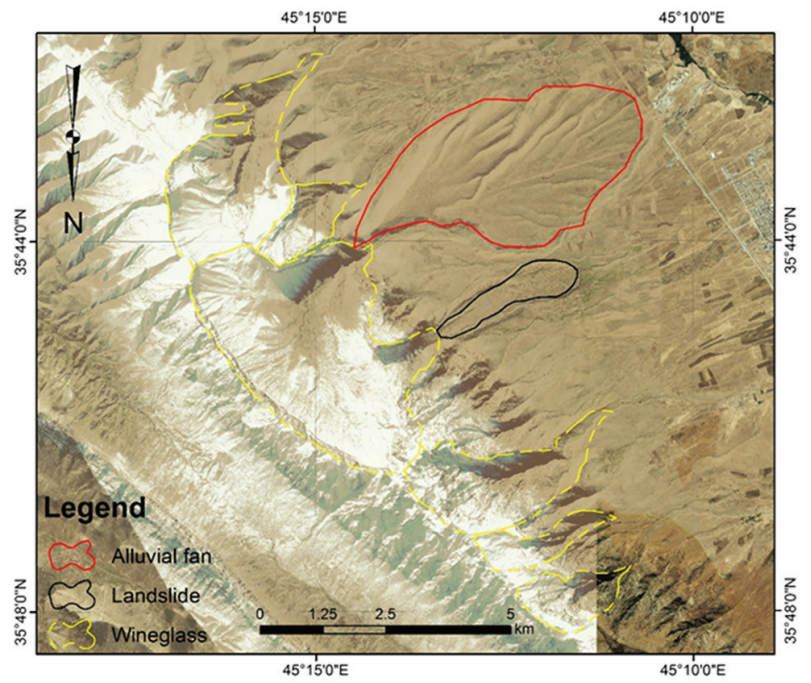

Fig. 4. QuickBird image, facing south of Pera Magroon anticline. Note the large-wine glass form (in yellow); the developed Zewe alluvial fan (in red) and Qara Chatan landslide (in black).

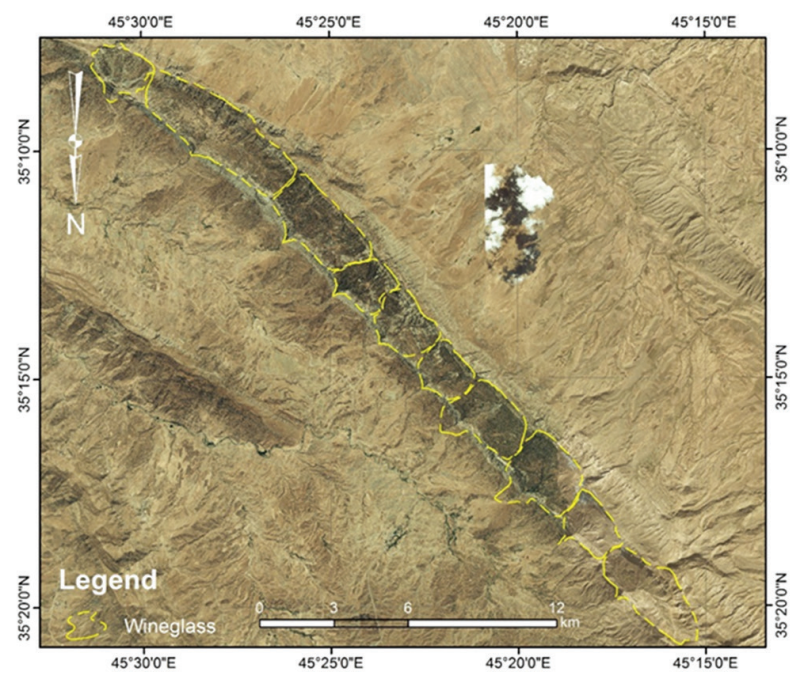

Fig. 5. QuickBird imagery of Qara Dagh anticline, note the developed wine-glasses (limited by yellow lines), most of the whole core of the anticline is occupied by wine-glass forms.

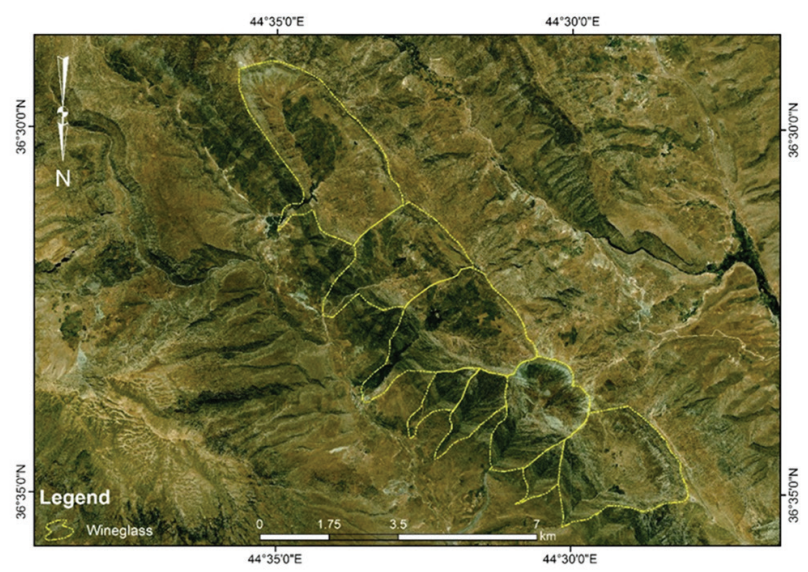

Fig. 6. QuickBird imagery of Korak anticline, note the developed wineglass forms. is large and deep with low gradient; hence, the difference on both sides of the outlet is not adequate to develop alluvial fan, (2) presence of another anticline or high ridge just after the outlet; hence no available area occurs for development of alluvial fan (Fig. 3, Point BS, between Bana Bawi and Safeen anticlines), and (3) presence of high anticlinal ridges in the form of cuestas and hogbacks in the outlet.

\section{Discussion}

\section{A. Development of Wine-glass Forms}

In the studied area, the authors have recognized that wineglass forms are developed in many anticlines, such as Qara Dagh (Fig. 5), Korak (Fig. 6), and Gara (Fig. 7) in which rocks older and/or younger than Cretaceous Period are exposed, more than those in which only Cretaceous rocks are exposed; like Hareer anticline (Fig. 8). Moreover, when only Cretaceous rocks are exposed in anticlines; then the majority of them exhibit whale back-shape structures (Fig. 8). This is attributed to the exposed very hard Cretaceous rocks. Some deeply cut valleys, however, occur in those anticlines, which will change; by time to wine-glass forms by continuous erosion.

The assumption of whale back-shape anticlines is based on the fact that the anticlines in which rocks older than Cretaceous Period are exposed wide anticlines, such as Gara (Figs. 2 and 7) and Pera Magroon (Fig. 4) anticlines. Moreover, the early Cretaceous succession, especially qamchuqa formation and late cretaceous bekhme formation include very thick and hard rocks, which are not easily eroded to exhibit wine-glass forms. On contrary, the Jurassic and even the Triassic successions include soft rocks in their upper parts (Sissakian and Fouad, 2012; Sissakian and Saeed, 2012), which were easily eroded and have developed tens of wine-glass forms. This process had exposed younger erosional surfaces (on Triassic and older rocks); in contrast to hard rocks, which show older erosional surfaces of Cretaceous and younger rocks without the presence of wineglass forms. A good example is Gara anticline (Figs. 2 and 7) in which Triassic rocks are exposed; the anticline exhibits 20 wine-glass forms; forming one extremely large wineglass form with many outlets, at opposite directions (Figs. 2 and 7).

In those anticlines where only the Cretaceous hard rocks are exposed and deeply eroded by galley shape valleys (Fig. 9) without wine-glass form development, they may exhibit wineglass forms in some parts due to either fault escarpments or when the older Qamchuqa Formation is exposed (Fig. 10). This is attributed to the presence of a 30-65 m thick soft succession between the Qamchuqa and Bekhme formations (Sissakian and Al-Jibouri, 2014; Sissakian and Youkhanna, 1979; Youkhanna and Sissakian, 1986).

To the contrary of the aforementioned cases, in some anticlines like Hareer (Figs. 8-10), for example, almost no wine-glass form is developed. This is attributed to: (1) The presence of the Bekhme Formation with very hard and thickly bedded carbonate rocks, (2) the Bekhme Formation forms the carapace of the mountain, with comparatively 


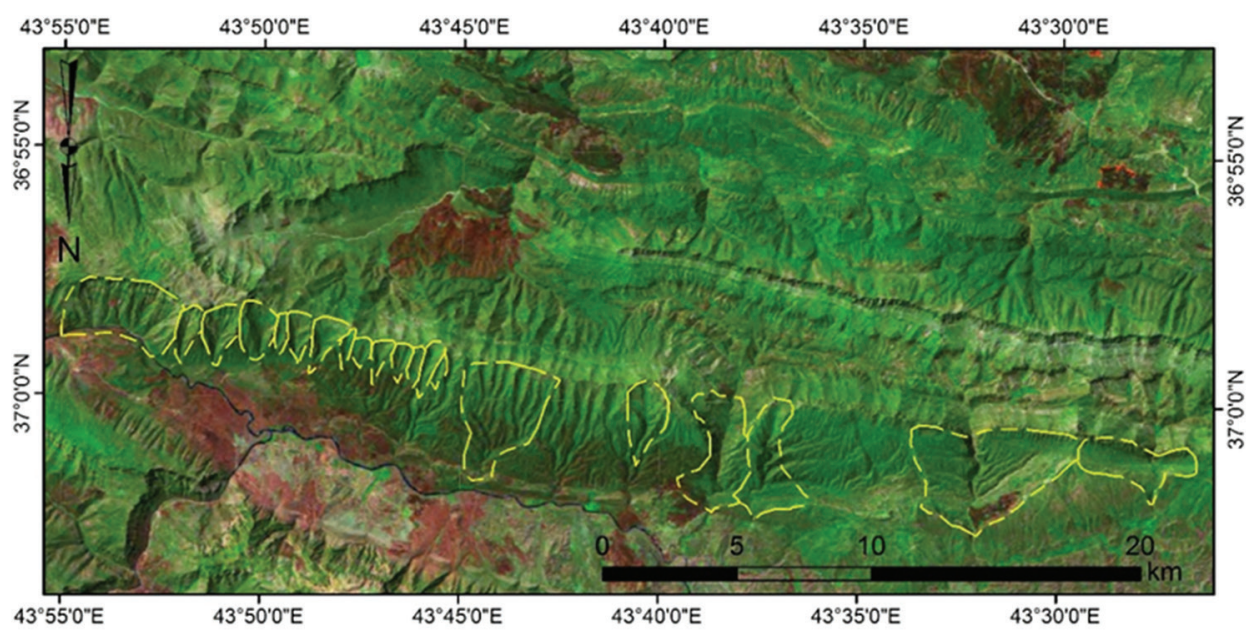

Fig. 7. Landsat image of Gara anticline, note the wine-glass forms (in yellow lines).

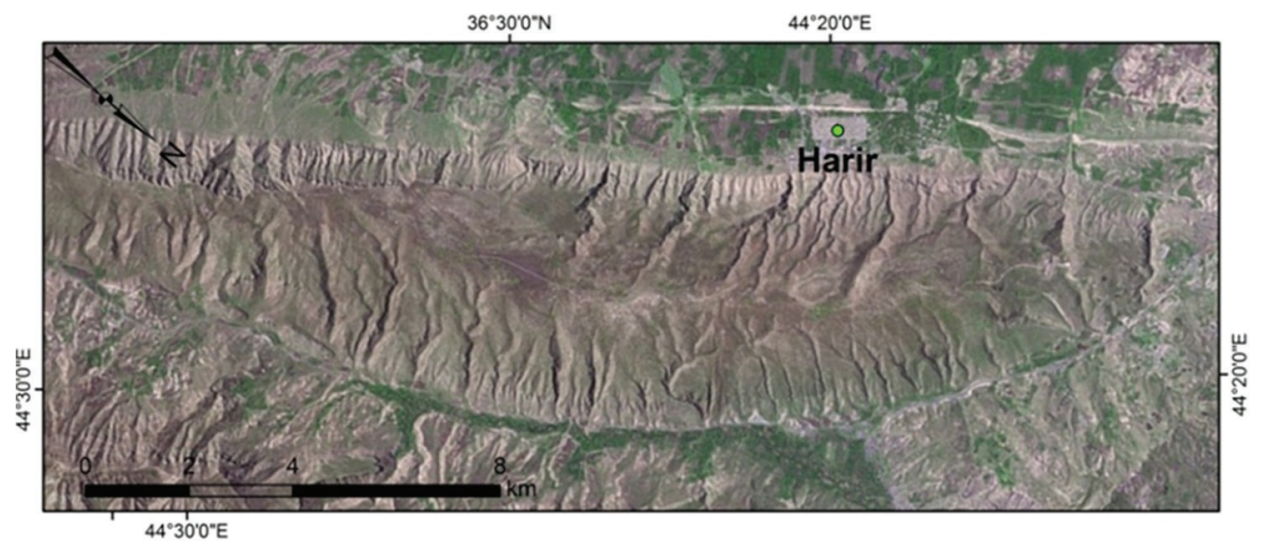

Fig. 8. Landsat image of Hareer anticline; facing $\mathrm{N} 135^{\circ}$ E. Note, the absence of wine-glass form, the presence of deeply cut valleys on both limbs and also note the whale back-shape of the anticline.

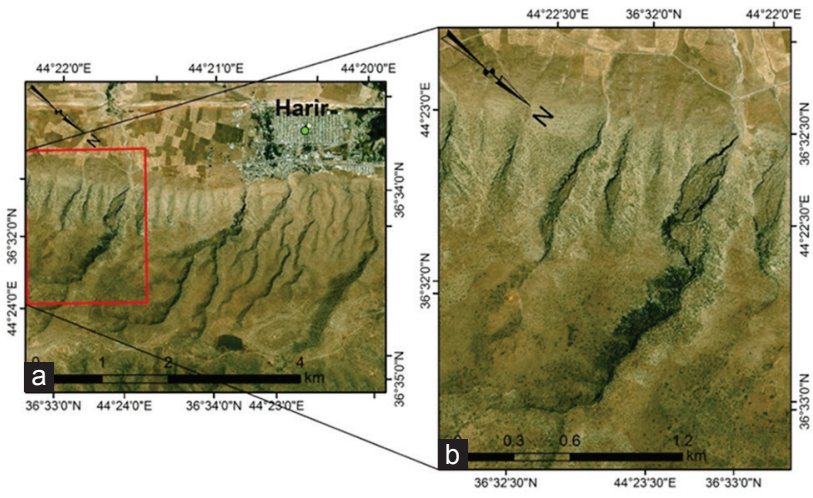

Fig. 9. (a) QuickBird imagery facing NE of Hareer anticline, note the deeply incised valleys without wine-glass form and (b) enlarged part of a deeply incised valley.

wide hinge zone, which decreases the distances between the tension and shear joints that consequently decreases the ability of weathering and erosion due to less disintegrated rocks, and (3) the wide hinge zone, which forms a wide plateau that behaves as retarder to the flowing rainwater on the top of the anticline; consequently, decreases the erosion ability, especially in the uppermost parts of the anticline. The steep limbs of Hareer anticline, however, exhibit sever gulley erosion in majority of the valleys (Figs. 8 and 9) forming deeply eroded valleys with the absence of wine-glass forms. This is attributed to: (1) Box fold shape of the anticline that makes the limbs become steep suddenly after the wide hinge zone, and (2) the steep limbs causes the exposure of the upper beds of the Bekhme Formation (Fig. 9), which are very hard without reaching the lower parts of the formation which includes softer rocks (Fig. 10). These are the main reason for the development of wine-glass forms in other anticlines which are not of box fold type.

Another example is Bana Bawi anticline (Fig. 3). It has very large wine-glass form and three outlets through gorges. In this anticline, the presence of thick and hard rocks of the Bekhme Formation in the core of the anticline and soft late Cretaceous and early tertiary rocks; Shiranish, Tanjero, Kolosh, and Gercus formations, which are overlain by hard rocks of the Pila Spi Formation (Fig. 3) is the reason of forming the extremely large wine-glass form. It is worth mentioning that the presence of large wine-glass forms is a result of conjugation of tens of small wine-glass forms that are widened continuously through the time by eroding the 


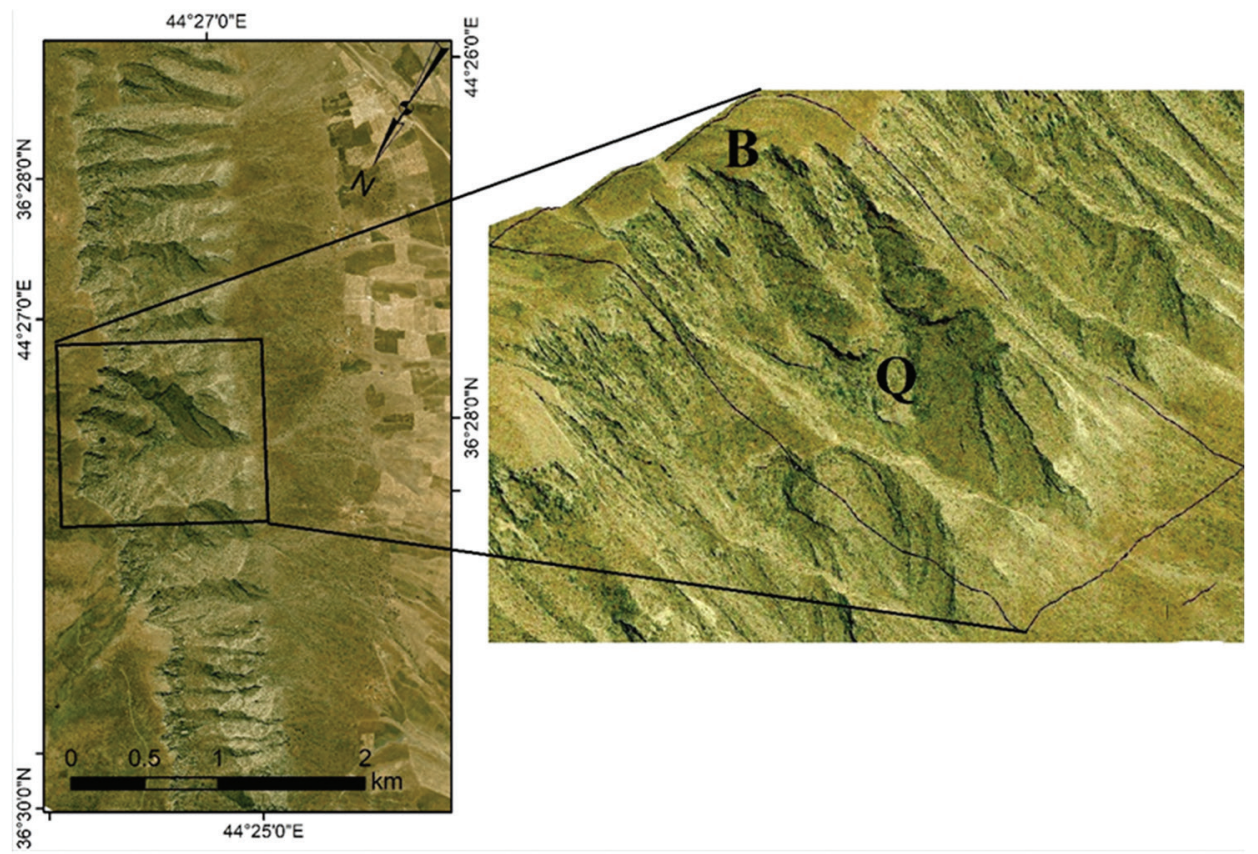

Fig. 10. QuickBird imagery of the eastern part of Hareer anticline (facing west). (a) Development of shallow wine-glass forms; due to continuous erosion and exposure of the Qamchuqa Formation, (b) 3D view enlarged image of a wine-glass form, includes Qamchuqa Formation (Q), and Bekhme Formation (B).
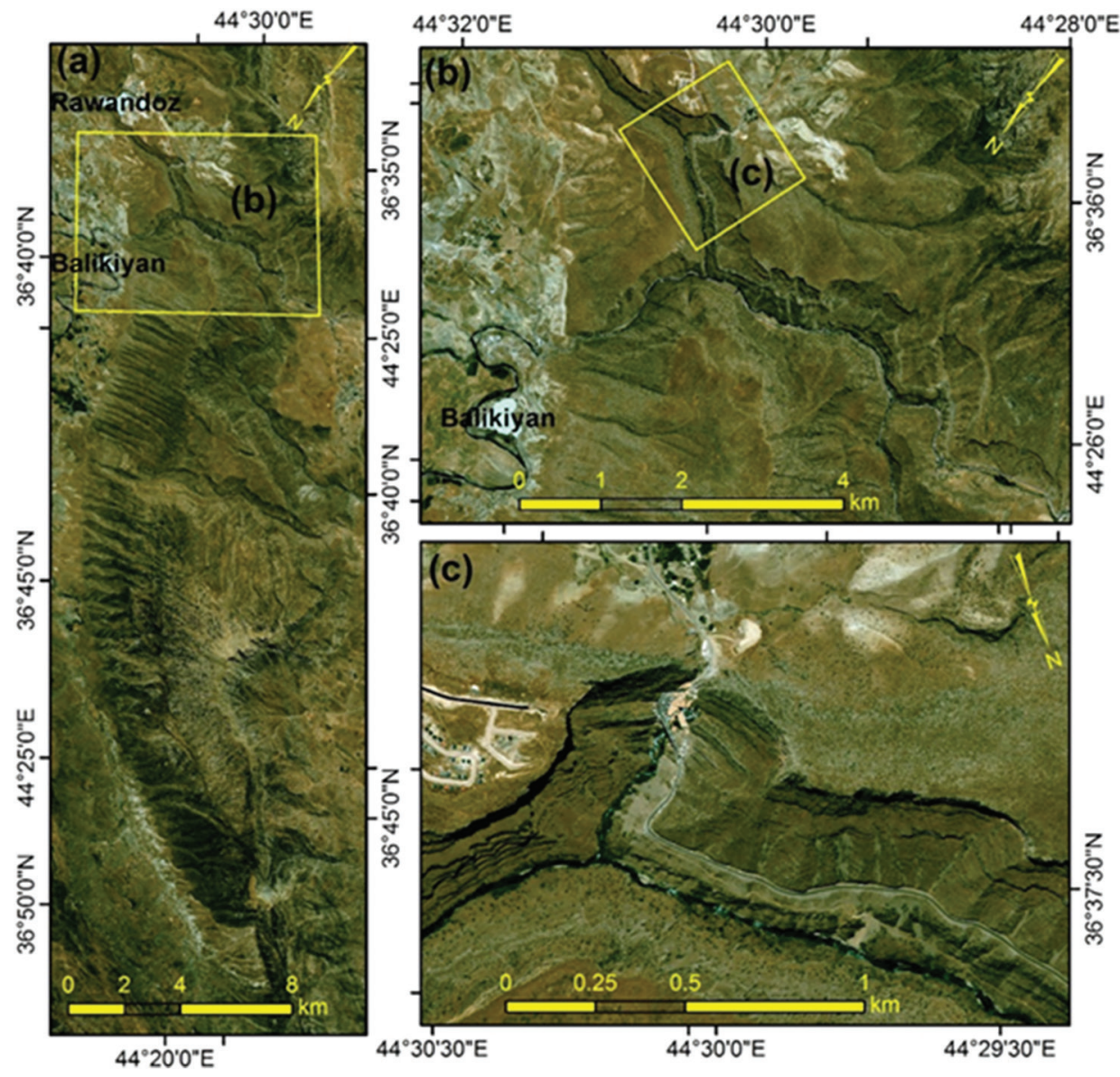

Fig. 11. (a) QuickBird imagery of Bradost anticline, (b) note the blocked inlet of a water gap, which forms a large and longitudinal wine-glass form, and (c) enlarged part of the blocked valley. 
divide walls in between two conjugate wine-glass forms, consequently, the formation of the existing extremely large wine-glass form.

\section{B. Development of Wine-glass Forms}

In the studied area, water and wind gaps are very common phenomena, Gara anticline exhibit both types of these gaps. If a fold starts to propagate laterally and the incision rate of the river is higher than the uplift rate of the fold, then a gorge called water gap (WG)," will be developed. If the incision rate of the river becomes lower than the uplift rate of the folds during further growth of the anticline, the river gets defeated and diverted leaving behind a dry valley called "wind gap" (Burbank et al., 1999; Burbank and Pinter, 1999 and Burbank and Anderson, 2000). Moreover, many geomorphological processes may contribute, accelerate or even form WG and change them to wind gaps; such as large landslides and development of alluvial fans (Sissakian and Abdul-Jabbar, 2010).

The developed water and wind gaps may contribute to the development of wine-glass forms or just the reverse. A WG may form a wine-glass form if one side of the WG is blocked by any reason. Good examples are blockage by mass movement phenomena and/or alluvial fans (Sissakian and Abdul-Jabbar, 2010). Such example is observed within Bradost anticline (Fig. 11a), where the northern inlet of a

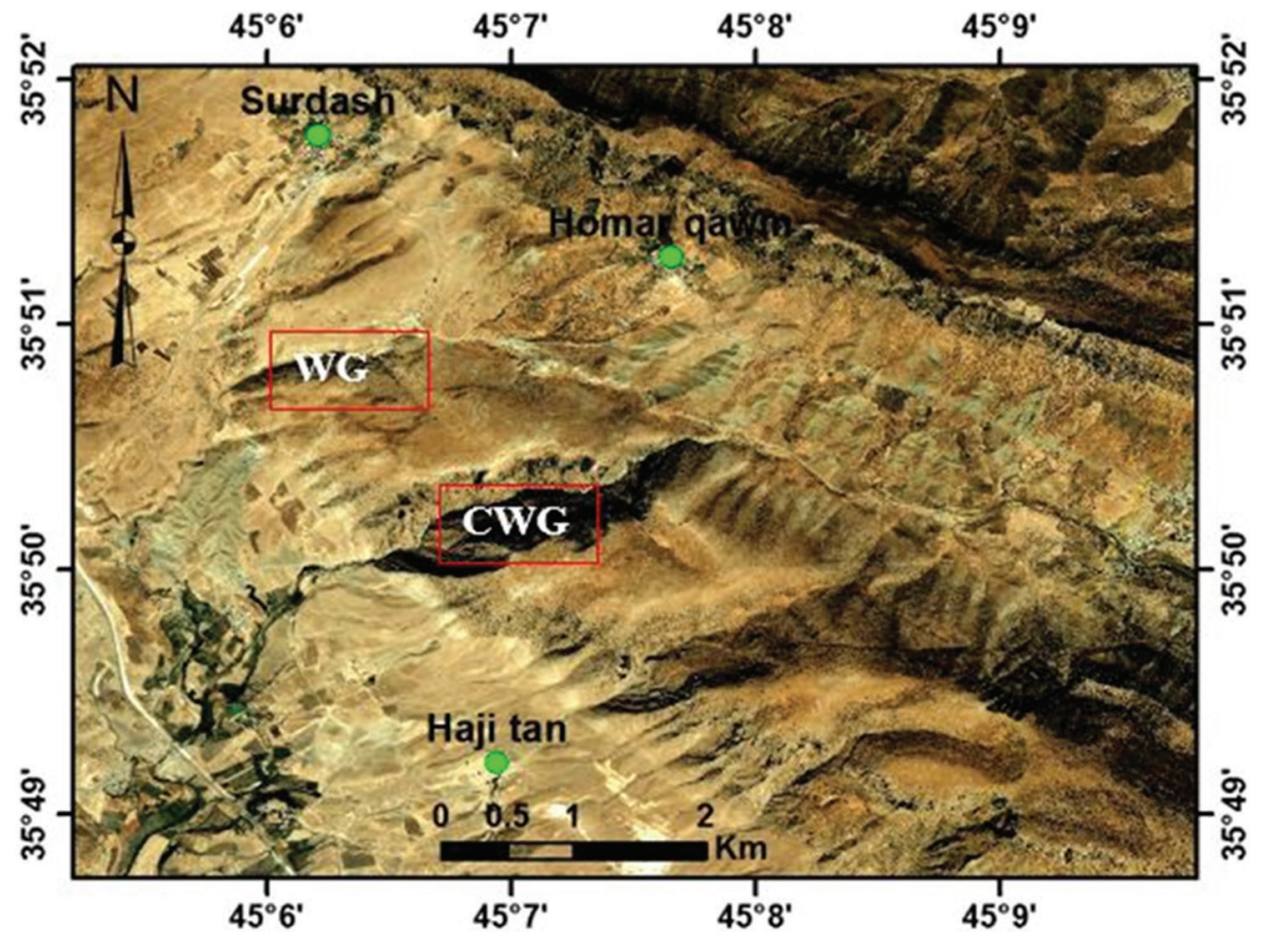

Fig. 12. QuickBird imagery showing the developed CWG and water gap in the northwestern part of Pera Magroon anticline.

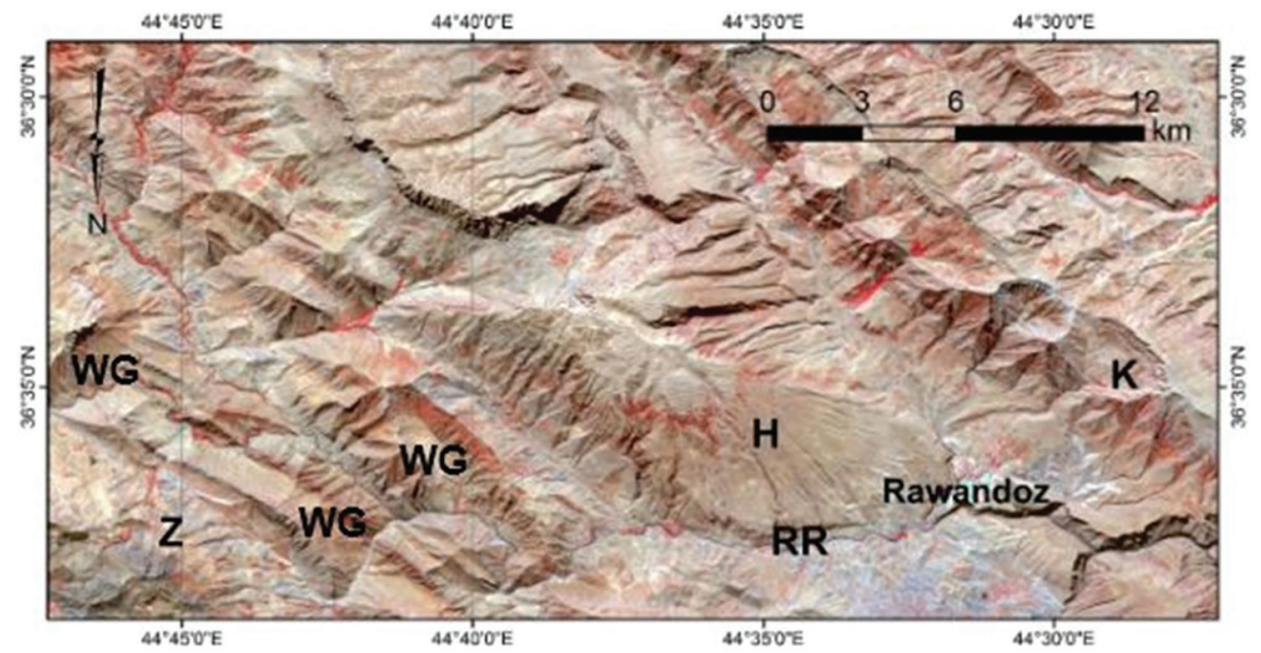

Fig. 13. ASTER image facing south. Note the Rawandoz River (RR); crossing Zozik (Z) and Handreen (H) anticlines. Note the developed wind gaps that are changed to wine-glass forms (WG), and the developed wine-glass forms in Korak anticline (K). 
WG is blocked by landslides (Fig. 11b); consequently, the WG is changed to wind gap, which represents a big wineglass form (Fig. 11c).

A special form of wind gaps, called "curved wind gaps (CWG)" occurs locally. These forms of wind gaps are developed in areas having high tectonic uplift and propagation rates with simultaneous low incision rates, due to very fast propagation and high tectonic uplift ratios of a fold growing in length (Ramsey et al., 2008). A good example is the developed curved water and wind gaps in the northwestern plunge of Pera Magroon anticline (Fig. 12).

It is worth to mention that there are tens of such curved water and wind gaps in different anticlines in the studied area (Sissakian and Abdul-Jab'bar, 2010). Those, CWG and/ or curved WG are more favorable areas for development of wine-glass forms, this is attributed to: (1) The curved valleys are usually more dissected on both sides by small rills; consequently, more widening occur to the valley, and (2) the curved valleys exhibit undercut erosion on their concave sides; consequently, more side erosion occurs that accelerates the development of wine-glass forms.

Drainage parallel to a fold axis will likely be diverted in the direction of propagation, as diversions develop, tributary streams are captured and the size of the upstream drainage basin increases until there is sufficient stream power to maintain a channel temporarily at the nose of the fold where propagation has not yet occurred (Keller and Pinter, 2002). This area becomes a WG and eventually defeated by uplift and/or stream capture, if defeat occurs, the channel may be

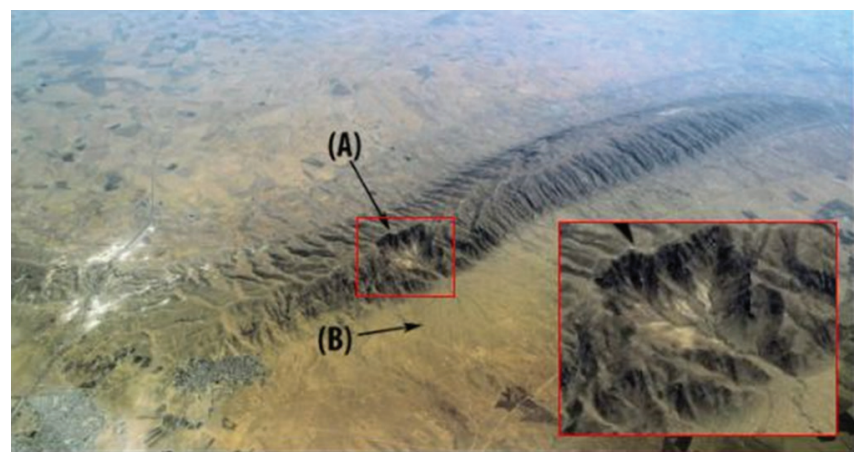

Fig. 14. Landsat image of Qara Chough anticline. Note the developed wine-glass form (a) and the alluvial fan in the outlet (b) and note the absence of the wine-glass forms in other parts of the whole anticline. diverted again in the direction of the lateral propagation, and in the course of a fold development, the channel may make several passes around the fold as the drainage develops. For some folds, there may be several wind gaps produced in this manner, and the drainage will be repeatedly diverted around the nose of the fold, consequently, many wine-glass forms will be developed. Good examples are Zozik and Handreen anticlines (Fig. 13).

\section{Development of wine-glass forms in cretaceous rocks}

as mentioned before, the authors have noticed that in the studied area, wine-glass forms are not developed in most of the anticlines where the Cretaceous rocks form the bulk of the anticline (carapace of the mountain); apart from the uppermost late Cretaceous rocks (Shiranish and Tanjero formations), which are mainly soft rocks with low resistance to weathering and erosion. However, some exceptions occur for this phenomenon in the southern part of the studied area, which belongs; tectonically to the Low Folded Zone (Fouad, 2012a) and "especially" in those areas where subsurface grabens were inverted to form anticlines after the Cretaceous Period (Fouad and Nasir, 2009); and partly Cretaceous rocks are exposed in their cores.

A good example is Qara Chough anticline (Fig. 14), it is a double plunging anticline; NW - SE trending, mainly Oligocene rocks are exposed in the core; forming the bulk of the anticline. In its northwestern part, a wine-glass form is developed; the exposed rocks belong to the Shiranish and Jaddala formations of uppermost late Cretaceous and Eocene age, respectively (Sissakian, 1993). The wine-glass form was called as "Azkand Cirque" by van Bellen et al. (1959), referring to the nearest village called Azkand.

The authors attribute the development of the wine-glass form in Qara Chough anticline to: (1) Highly fractured Oligocene rocks, (2) the presence of many diagonal faults (Sissakian, 1993); nearby to the wine-glass form, which had increased the fracture system of the rocks; consequently, decreased the weathering resistance, and (3) the anticline, as many others westward, was originally grabens and was inverted to anticlines after Cretaceous period (Fouad, 2012b; Fouad and Nasir, 2009); therefore, the involved area may had suffered from maximum upward forces, as compared to the remaining area, consequently the wine-glass form is developed in which the Shiranish Formation is exposed

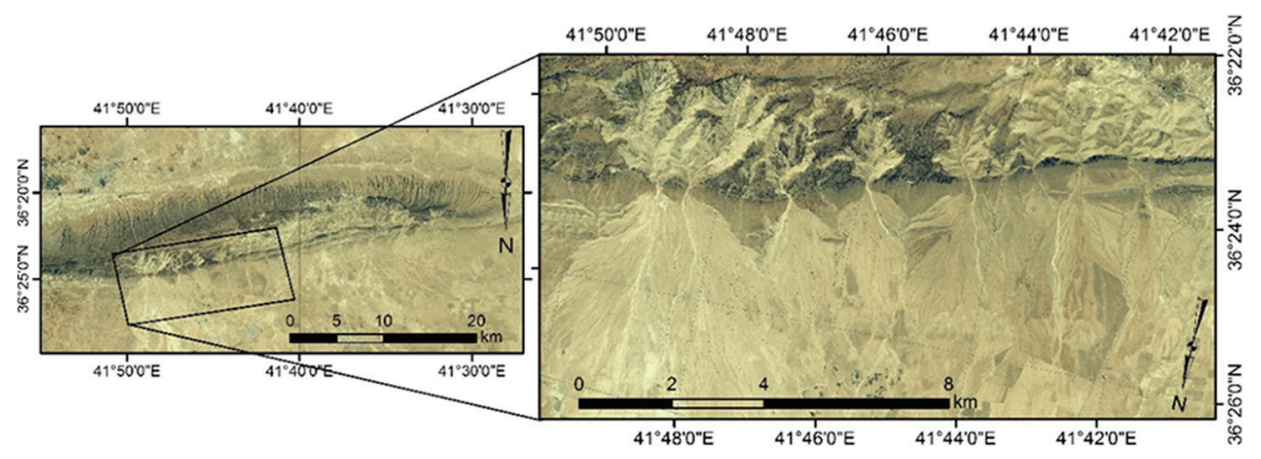

Fig. 15. Landsat image facing south of Sinjar anticline. Note the densely developed wine-glass forms and the related developed alluvial fans. 
with Sinjar and Aaliji formations, both of Paleocene age, and the later consists of soft shale and marl (Sissakian and Saeed, 2012).

Another good example for the development of wine glass forms in exposed Cretaceous rocks is Sinjar anticline (Fig. 15) in the northwestern part of Iraq; it is a double plunging and $\mathrm{E}-\mathrm{W}$ trending anticline. The Sinjar Formation of Paleocene age forms the carapace of the mountain, the formation consists of hard and thick limestone, it is underlain by the Shiranish Formation; it consists of thinly well-bedded limestone and papery marl (Sissakian and Fouad, 2012; Sissakian and Saeed, 2012), both rocks are weakly resistant to weathering and erosion.

The authors attributed the development of wine-glass forms in Sinjar anticline to: (1) The presence of a long fault parallel to the axis of the anticline (Sissakian et al., 1995), (2) the exposure of the Shiranish Formation with its weak rocks, (3) the anticline, as many others in the Jazira Plain, was originally grabens and was inverted to anticlines after Cretaceous period (Fouad, 2012b; Fouad and Nasir, 2009); therefore, the involved area had suffered from upward forces; consequently, the Shiranish Formation is exposed with the Sinjar and Aaliji formations, both of Paleocene age, and the later consists of soft shale and marl (Sissakian and Saeed, 2012), which are the main source for the sediments of the alluvial fans.

\section{Conclusions}

This study demonstrates the erosional forms called cirque or wine-glass forms, which are developed intensely in several anticlines located in the Kurdistan region, north and northeast of Iraq. Many materials were used to perform this study and achieve these conclusions, such as geological and topographical maps, DEM, and satellite images such as Landsat, and QuickBird data, and relevant published articles and reports. The current work has concluded that the wine-glass forms are well developed in the majority of the existing anticlines in the studied area. Anticlines in which the Cretaceous rocks form the carapace, very rarely or no wine glass-forms are developed. When rocks older or younger than Cretaceous period are exposed in the core of an anticline, then wine-glass forms are densely formed there. Moreover, the core of some anticlines exhibits many wine-glass forms; therefore, the whole core resembles one very large wineglass form. The development and enlargement of wine-glass forms are a continuous process; still ongoing. Many wineglass forms will merge to neighboring forms, as indicated from the thin divide cliff in between two conjugate forms, thus forming a large-wine glass form.

\section{REFERENCES}

Alden, A., 2014. Erosional Landforms. In: GEO ExPro Magazine.

Al-Jaf, A.A. and Kadhim, T.H., 2010. The Geomorphological Map of Kirkuk Quadrangle, Sheet No. N1-38-2, Scale 1:250000. Iraq Geological Survey Library, Report No. 3297, Baghdad, Iraq.

Al-Ma'amar, A.F., Al-Saady, Y.I. and Al-Saati, R.M., 2011. Series of
Geomorphological Maps of Iraq, scale 1: 250000, Erbil and Mahabad Quadrangles, Sheets No. NJ-38-14 and NJ-38-15. Iraq Geological Survey Library, Report No. 3358.

Al-Mousawi, H.A., Sissakian, V.K. and Fouad, S.F., 2008. The Geology of Zakho Quadrangle, Scale 1:250000. Iraq Geological Survey Publications, Baghdad, Iraq.

Bahrami, S., 2012. Morphotectonic evolution of triangular facets and wine-glass valleys in the Noakoh anticline, Zagros, Iran: Implications for active tectonics. Geomorphology, 159-160, pp.37-49.

Burbank, D.W. and Anderson, R.S., 2000. Tectonic Geomorphology. Wiley, New York.

Burbank, D.W. and Pinter, N., 1999. Landscape evolution: The interactions of tectonics and surface processes. Basin Research, 11(1), pp.1-6.

Burbank, D.W., McLean, J.K., Bullen, M.Y. and Miller, M.M., 1999. Partitioning of intermontane basins by thrust-related folding. TienShan, Kyrgyzstan. Basin Research, 11(1), pp.75-92.

DigitalGlobe, 2006. Quickbird Imagery Products: Product Guide, 4.7.1 ed. DigitalGlobe, Inc., Longmont, CO., USA.

Evans, I.S. and Cox, N., 1974. Geomorphometry and the operational definition of cirques. The Royal Geographical Society, 6(2), pp.150-153.

Fouad, S.F., 2007. The Geology of Kani Rash Quadrangle, Scale 1:250000. Iraq Geological Survey Publications, Baghdad, Iraq.

Fouad, S.F., 2012a. Tectonic Map of Iraq, Scale 1:1000 000. $3^{\text {rd }}$ ed. Iraq Geological Survey Publications, Baghdad, Iraq.

Fouad, S.F., 2012b. Western zagros thrust-fold belt. Part 1: The low folded zone. In: Geology of the low folded zone. Iraqi Bulletin of Geology and Mining, 5, pp.39-62.

Fouad, S.F.A. and Nasir, W.A.A., 2009. Tectonic and structural evolution. In: Geology of Al-Jazira area. Iraqi Bulletin of Geology and Mining, 3, pp.33-48.

Gornitz, V., 2009. Encyclopedia of Paleoclimatology and Ancient Environments. $1^{\text {st }}$ ed. Springer, Netherlands.

Hamza, N.M., 1997. Geomorphological Map of Iraq, Scale 1:1000 000. Iraq Geological Survey Publications, Baghdad, Iraq.

Huggett, R., 2007. Routledge Fundamentals of Physical Geography. In: Fundamentals of Geomorphology. $2^{\text {nd }}$ ed. Taylor and Francis, London.

Keller, E.A. and Pinter, N., 2002. Hall earth science series. In: Active Tectonics: Earthquakes, Uplift, and Landscape. Prentice Hall, New Jersey.

Mitchell, S.G. and Humphries, E.E., 2014. Glacial cirques and the relationship between equilibrium line altitudes and mountain range height. Geology, 43(1), pp.35-38.

Othman, A.A. and Gloaguen, R., 2013a. River courses affected by landslides and implications for hazard assessment: A high resolution remote sensing case study in NE Iraq-W Iran. Remote Sensing, 5(3), pp.1024-1044.

Othman, A.A. and Gloaguen, R., 2013b. Automatic extraction and size distribution of landslides in Kurdistan region, NE Iraq. Remote Sensing, 5(5), pp.2389-2410.

Othman, A.A. and Gloaguen, R., 2014. Improving lithological mapping by SVM classification of spectral and morphological features: The discovery of a new chromite body in the mawat ophiolite complex (Kurdistan, NE Iraq). Remote Sensing, 6(8), pp.6867-6896.

Ramsey, L.A., Walker, R.T. and Jackson, J., 2008. Fold evolution and drainage development in the Zagros mountains of Fars province, SE Iran. Basin Research, 20(1), pp.23-48.

Sissakian, V.K. and Abdul-Jab'bar, M.F., 2010. Morphometry and genesis of the main transversal gorges in North and Northeast Iraq. Iraqi Bulletin of Geology and Mining, 6(1), pp.95-120. 
Sissakian, V.K. and Al-Jibouri, B.S., 2014. Stratigraphy, In: Geology of the high folded zone. Iraqi Bulletin of Geology and Mining, 6, pp.73-16.

Sissakian, V.K. and Fouad, S.F., 2012. Geological Map of Iraq, Scale 1:1000 000. $4^{\text {th }}$ ed. Iraq Geological Survey Publications, Baghdad-Iraq. Available from: http:// www.iasj.net/iasj?func $=$ fulltext\&aId=99666. [Last accessed on 2017 Nov 12].

Sissakian, V.K. and Fouad, S.F., 2014a. The Geology of Sulaimaniyah Quadrangles, Scale 1:250 000, Sheet No. NI-38-03. $2^{\text {nd }}$ ed. Iraq Geological Survey Publications, Baghdad, Iraq.

Sissakian, V.K. and Fouad, S.F., 2014b. The Geology of Erbil and Mahabad Quadrangles, Scale 1:250 000, Sheets No. NJ-38-14 and NJ-38-15. $2^{\text {nd }}$ ed. Iraq Geological Survey Publications, Baghdad, Iraq.

Sissakian, V.K. and Fouad, S.F., 2014c. The Geology of Kirkuk Quadrangle, Scale 1:250 000, Sheet No. NI-38-2. $2^{\text {nd }}$ ed. Iraq Geological Survey Publications, Baghdad, Iraq.

Sissakian, V.K. and Ibrahim, F.A., 2004a. Geological Hazards Map of Mosul Quadrangle, Scale 1:250 000, Sheet No. NJ-38-03. In: Iraq Geological Survey Library, Report No. 2860.

Sissakian, V.K. and Ibrahim, F.A., 2004b. Geological Hazards Map of Erbil and Mahabad Quadrangles, Scale 1: 250 000, Sheets No. NJ-38-14 and NJ-38-15. In: Iraq Geological Survey Library, Report No. 2878.

Sissakian, V.K. and Ibrahim, F.A., 2005. Geological Hazards Map of Iraq, Scale 1:1000 000. Iraq Geological Survey Publications, Baghdad, Iraq.

Sissakian, V.K. and Saeed, Z.B., 2012. Lithological map of Iraq, compiled using GIS techniques. Iraqi Bulletin of Geology and Mining, 8(3), pp.1-13.

Sissakian, V.K. and Youkhanna, R.Y., 1979. Report on Regional Geological Mapping of Erbil-Shaqlawa-Koi Sanjaq-Raidar Area. In: Iraq Geological Survey Library, Report No. 975.

Sissakian, V.K., 1993. Geological Report on Kirkuk Quadrangle, Sheet No. NI-38-02, Scale 1:250 000. Iraq Geological Survey Publications, Baghdad, Iraq.

Sissakian, V.K., 1995. Geological Report on Al-Mosul Quadrangle, Sheet No. NJ-38-03, Scale 1:250 000. Iraq Geological Survey Publications, Baghdad, Iraq.
Sissakian, V.K., 2010. Neotectonic movements in Darbandi Bazian area, Southwest of Sulaimaniyah city, NE Iraq. Iraqi Bulletin of Geology and Mining, 6(2), pp.57-69.

Sissakian, V.K., 2013. Geomorphology and morphometry of the greater Zab river basin, North of Iraq. Iraqi Bulletin of Geology and Mining, 9(3), pp.21-49.

Sissakian, V.K., Kadhum, T.H. and Jab'bar, M.A., 2014. Geomorphology. In: Geology of the high folded zone. Iraqi Bulletin of Geology and Mining, 6, pp.7-56.

Sissakian, V.K., Qambar, A.S. and Ahad, A.D.A., 2008a. Geological Hazards Map of Zahko Quadrangle, Scale 1:250 000, Sheet No. NJ-38-9. Iraq Geological Survey Library, Report No. 3129.

Sissakian, V.K., Qambar, A.S. and Ahad, A.D.A., 2008b. Geological Hazards Map of Sulaimaniyah Quadrangle, Scale 1:250 000, Sheet No. NI-38-03. Iraq Geological Survey Library, Report No. 3075.

Sissakian, V.K., Qambar, A.S. and Ahad, A.D.A., 2008c. Geological Hazards Map of Kani Rash Quadrangle, Scale 1:250 000, Sheet No. NJ-38-10. Iraq Geological Survey Library, Report No. 3112.

Upton, B.G.J. and Wadsworth, W.J., 1969. Early volcanic rocks of réunion and their tectonic significance. Bulletin Volcanologique, 33(4), pp.1246-1268

van Bellen, R.C., Dunnington, H.V., Wetzel, R. and Morton, D., 1959. Lexique Stratigraphic International. Asie, Fasc, Iraq, Paris.

Ward, D., Saltz, D. and Olsvig-Whittaker, L., 2000. Distinguishing signal from noise: Long-term studies of vegetation in Makhtesh Ramon erosion cirque, Negev desert, Israel. Plant Ecology, 150(1-2), pp.27-36.

Wikipedia, 2014. Fluvial-Erosion Cirque Formation. Available from: https:// www.en.wikipedia.org/wiki/Cirque. [Last accessed on 2017 Aug 18].

Yacoub, S.Y., Othman, A.A. and Kadhum, T.H., 2012. Geomorphology. In: Geology of the low folded zone. Iraqi Bulletin of Geology and Mining, 5, pp.7-38.

Youkhanna, R.Y. and Sissakian, V.K., 1986. The Stratigraphy of the ShaqlawaKoisanjaq Area. In: Proceedings of the $7^{\text {th }}$ Iraqi Geological Congress, $12-15 / 4 / 1986$, Baghdad, Iraq. 